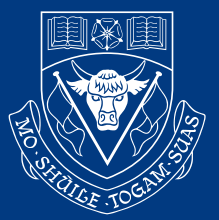

UNIVERSITY OF CALGARY
THE SCHOOI/
SPP Research Papers The Health Series

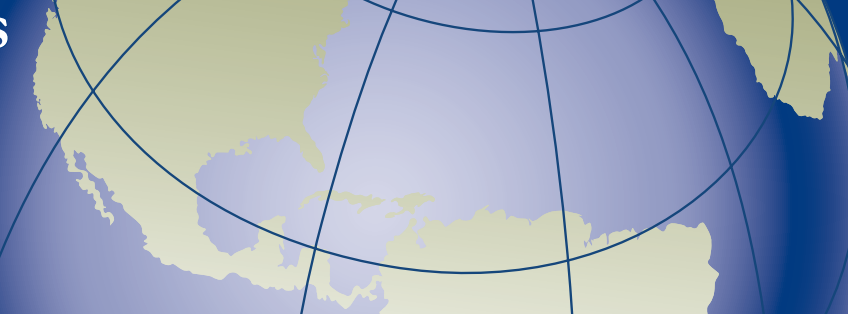

Volume $2 \cdot$ Issue $3 \cdot$ June 2009

\title{
THE PRIVATE INSURANCE DEBATE IN CANADIAN HEALTH POLICY: \\ MAKING THE VALUES EXPLICIT
}

\section{Michael Yeo, J.C. Herbert Emery, and Daniel Kary}

\section{SUMMARY}

Should Canadian governments prohibit private insurance for services parallel to those provided in the publicly insured health care system? We believe that the values engaged by this issue have not been made clear and explicit in health policy discussion and debate. With reference to the recent Chaoulli case at the Supreme Court of Canada, we articulate what we take to be the main values in tension and conflict, and distinguish three main value-based positions on the policy issue. By doing so we hope to contribute to a more informed, explicit and open public policy discussion. 


\section{INTRODUCTION}

Canada's single-payer public health insurance systems are for the most part financed out of the general revenues of the federal and provincial governments. ${ }^{l}$ Since the passage of the 1984 Canada Health Act, private payment for health care has been an exclusive (opting out) alternative for service providers, rather than a supplement, to publicly financed health care services provided in hospitals and/or by a physician. ${ }^{2}$ The policy objective of the Act is to "facilitate reasonable access to health services without financial or other barriers" (s.3) with the establishment of "criteria and conditions in respect of insured health services and extended health care services provided under provincial law that must be met" (s.4) for a province to receive a full cash contribution from the federal government. To meet the conditions of the Act, provinces have regulated and, in some cases, prohibited private insurance for publicly insured services. ${ }^{3}$

Should Canadian governments prohibit private insurance for services parallel to those provided in the publicly insured health care system? Controversy about this divisive and contentious issue in Canadian health policy came to a head during the Supreme Court of Canada decision in Chaoulli v. Quebec (hereafter Chaoulli) ${ }^{4}$ about a legislative prohibition against private insurance in the province of Quebec. The narrowly circumscribed legal issue before the Court — is the prohibitive measure legally justified? — intersects the policy issue, but was not the controversial policy issue as such. ${ }^{5}$ Moreover, the Court's decision about the legality of the prohibition came to turn on whether private insurance would diminish the quality of the publicly funded health care system. This empirical question has an important bearing on the policy issue and divisions of opinion concerning it, but also is not the policy issue as such.

$\bar{l}$ Canada does not have one single health care system as each province and territory administers its own according to the conditions defined by the Canada Health Act. For a discussion of how varied the systems are, see G.W. Boychuk, "The Regulation of Private Health Funding and Insurance in Alberta under the Canada Health Act: A Comparative Cross-Provincial Perspective," SPS Research Paper: The Health Series 1 (Calgary: University of Calgary, School of Policy Studies, December 2008).

2 Canada's public share of health care finance was around the OECD average of 74\%, but in other OECD countries private payment allows individuals to supplement the quantity and quality of publicly provided health care. Canada reserves private payment for non-medicare categories of health care expenditures such as long-term care, drugs, and non-physician-provided services. See Miguel Gouveia, "Majority Rule and the Public Provision of a Private Good," Public Choice 93 (3-4, 1997): 221-244.

Throughout this paper, when we speak of private insurance, it is always with respect to services parallel to those provided in the publicly funded system.

3 This response has occurred even though, as Boychuk points out, the Act does not require such regulations or prohibitions; instead, it requires that, in order to qualify for full federal funding, provincial public health insurance coverage must be universally available on uniform terms and conditions without any barriers to reasonable access, including barriers of a financial nature; see Boychuk, "The Regulation of Private Health Funding and Insurance in Alberta," p. 3.

4 Supreme Court of Canada, Chaoulli v. Quebec (Attorney General), [2005] 1 S.C.R. 791, 2005 SCC 35.

5 If the prohibition were in violation of the Canadian Charter of Rights and Freedoms,' that would be a very good policy reason against it, but even so, Quebec would have the option of using the "notwithstanding" clause. Alternatively, it could be argued that if the Quebec government rewrote the legislation in such a way as to explicitly include and reference in its purpose the protection of equality in the absolute egalitarian sense, a Charter challenge to a prohibition in that legislation might not succeed. 
The policy issue as such is not the proper affair of the courts, and is not reducible to an empirical issue concerning the effects of private insurance on the publicly funded system. ${ }^{6}$ It is ultimately and essentially about values in tension or conflict. This values issue was in the background in Chaoulli but was not frontally addressed, and given the limited mandate of the Supreme Court, could not be. We believe that, notwithstanding the commentary that has ensued in light of Chaoulli, the policy issue has not been debated as explicitly as it can and should be with reference to the values engaged and in tension.

To be sure, talk about values has figured rather prominently in the public debate about private insurance. Roy Romanow's Commission of the Future of Health Care in Canada titled its report Building on Values. ${ }^{7}$ Romanow believes that Canada's choice of a single-payer system is grounded in what he claims are "core values on which our health care system is premised equity, fairness, and solidarity." " $\mathrm{He}$ and others invoke these values to rule out private payment for publicly insured services as a morally feasible option for reforming health care finance and delivery in Canada. ${ }^{9}$ However, these allegedly core values have not been well defined with reference to important differences and nuances in their interpretation that bear on the answer to the policy question. Moreover, Romanow leaves out of his account other important values with which the ones he references are in tension. Without reference to these other values, and to the necessity of tradeoffs among them, the ones he invokes are vague and platitudinous.

Our objective in this paper is to make explicit and clarify the fundamental values in tension in the private insurance issue and to differentiate values-based positions concerning it. We adopt the Chaoulli case as the point of departure for our analysis, for three main reasons.

First, although the Supreme Court of Canada approached private insurance in narrowly constrained legal terms, its decision became a lightning rod for public policy discussion and an essential point of reference. ${ }^{10}$

6 A central issue raised by Chaoulli, and discussed by the Justices themselves, concerns the proper role of the courts in determining public policy. The standard view, which we share, is that the legislature makes or sets policy, and the judiciary checks policy that is thus set against constitutional norms. As Deschamps J. puts it at para. 89, "The courts have a duty to rise above political debate. They leave it to the legislatures to develop social policy." In so many words, the Minority accused the Majority of crossing this line and usurping the proper role of legislators.

7 Roy J. Romanow, Building on Values: The Future of Health Care in Canada. Final Report of the Commission on the Future of Health Care in Canada (Ottawa: Queen's Printer, 2002), p. xvi.

8 It is notable that the Senate report of the committee chaired by Michael Kirby agreed on the maintenance a singlepayer public system, even though both it and the Romanow report had some fundamental differences in terms of other policy proposals for the health care system; see Michael J.L. Kirby, The Health of Canadians - The Federal Role: Final Report on the State of the Health Care System in Canada (Ottawa: Senate, Standing Committee on Social Affairs, Science and Technology, 2002). Thomas Courchene compares and contrasts the values underlying the Romanow and Kirby reports, but his discussion leaves these values quite general and vague; see "Medicare as a Moral Enterprise: The Romanow and Kirby Perspectives," IRPP Policy Matters 4 (1, 2003): 1-20. To rule out the policy option of private payment and insurance, supposedly "core national values" are invoked by Theodore R. Marmor, K.G.H. Okma, and S.R. Latham, "National Values, Institutions and Health Policies: What Do They Imply for Medicare Reform?" Commission on the Future of Health Care in Canada Discussion Paper 5 (Ottawa, 2002).

10 Most of the main health care lobby groups positioned themselves on the case. Media coverage of the decision was extensive. Within months, two law conferences were held on the decision. 
Second, the lines of argument in Chaoulli, if freed from the legal constraints to which they were bound, make a good starting point for articulating and focusing the essential values in tension in the policy issue and for distinguishing fundamental value-based positions concerning it.

Third, critics have charged that debate about the empirical issue in Chaoulli was inexplicitly and illicitly infused with and informed by values. Whether or not this occurred in the Court, we believe that it does occur in public policy discussion that is not as constrained as was the discussion in the Court. Indeed, we believe that, in public discussion, the empirical dispute in the Court about the effect of private insurance became a proxy for a subterranean dispute about values. To make the values in tension explicit and to clarify the dispute about them, it is therefore necessary to separate the narrower empirical issue from the broader policy issue.

The paper proceeds as follows. We begin by setting Chaoulli in context and relating the main facts of the case. We then outline how the legal issue came to turn explicitly upon an empirical side issue about the hypothesized effects of private insurance on the publicly funded health system. The stage thus set, we free the analysis from the constraints of legal argument and turn directly to the policy issue that the Court did not and could not frontally address. Using the lines of argument and division in the Court as a starting point, we identify three main values engaged by the policy issue: welfare, equality, and liberty. With reference to these values in tension, we distinguish three main values-based positions concerning the policy issue: welfare egalitarianism, absolute egalitarianism, and libertarianism. We then offer reasons for supposing that value positions and judgments concerning the policy issue inexplicitly and illicitly may enter into and be masked by dispute about the empirical issue. Finally, in our conclusion, we summarize the central points of our analysis and say how we think it can be helpful for bringing greater explicitness, clarity, openness, and transparency into the public policy debate about private insurance and private payment in general. 


\section{THE CHAOULLI CASE AND ITS BACKGROUND}

Chaoulli v. Quebec originated with retired Montreal businessman George Zeliotis. In 1996, he discovered that he needed hip-replacement surgery and would have to wait approximately a year for the surgery through the Quebec public health care system. He also learned that Quebec law prohibited private insurance for publicly insured services. ${ }^{11}$ Zeliotis joined forces with Dr. Jacques Chaoulli, a physician interested in providing health care services outside of Quebec's public health care system, to challenge the prohibition in Quebec's Health Insurance Act and Hospital Insurance Act.

Chaoulli and Zeliotis challenged that the provisions in the Quebec legislation were illegal or unconstitutional under both Quebec's Charter of Human Rights and Freedoms and Canada's Charter of Rights and Freedoms. ${ }^{12}$ As McLachlan C.J. et al. summarized the challenge: "The appellants...seek a ruling that because delays in the public system place their health and security at risk, they should be allowed to take out insurance to permit them to access private services" (Chaoulli, para. 105). A majority of the seven Justices who sat the case agreed, and ruled that Quebec's ban on private health insurance was not justifiable under Quebec's Charter. $^{13}$

\section{How the Legal Issue Came to Turn Upon an Empirical Issue}

The issue at the Supreme Court of Canada was in the first instance a legal issue concerning the consistency of the Quebec statutes prohibiting private insurance with Charter rights. That legal issue came to turn decisively upon an empirical issue - namely, whether the prohibition was necessary for preserving the quality of the publicly funded system.

11 Paying out of pocket for private surgery in the United States (or elsewhere) was far beyond his financial means. Of course, private insurance would not have helped him at the time as he would have been ineligible due to a "preexisting condition."

12 Quebec courts had twice rejected Zeliotis's and Chaoulli's case. For detailed background on the progress of the case through the lower courts, see C.P. Manfredi and A. Maioni, "The Last Line of Defence for Citizens: Litigating Private Health Insurance in Chaoulli v. Quebec,” Osgoode Hall Law Journal 44 (249, 2006): 2-17.

13 There was no Majority decision that the prohibition violated the Canadian Charter. Three Justices ruled that it violated both the Canadian Charter and Quebec Charter, while three ruled that it did not. The seventh Justice ruled only that the prohibition violated Quebec's Charter and rendered no judgment on the Canadian Charter. Since the Supreme Court's decision for Quebec, similar challenges to the legality of prohibitions against private insurance have been mounted in Alberta and Ontario and one may be mounted in British Columbia; see Sam Solomon, "Chaoulli Copycat Cases Crop Up across Country,” National Review of Medicine 4 (1, 2007). 
The Justices rendered three separate judgments; two on the side of the Majority (Deschamps, J., who considered only the Quebec and not the Canadian Charter, and McLachlan, C.J., and Major J., Bastarche J. concurring) and one on the side of the dissenting Minority (Binnie and LeBel JJ., Fish J. concurring). ${ }^{14}$ The two Majority opinions agreed that the prohibition was indeed in breech of s. 1 of the Quebec Charter ("right to life, and to personal security, inviolability, and freedom"). ${ }^{15}$ However, the Quebec Charter allows that, if certain conditions are met, such a violation may be justified under s. 9.1. The two Majorities also agreed that these conditions were not met. Deschamps J. went no further in her analysis. However, McLachlin C.J. et al. and the Minority also analyzed the case under the Canadian Charter, which involved a two-step process similar to the Quebec Charter. In both cases, the issue distilled to whether a legislative measure found to be in violation of a provision similar in both charters (s.1 of the Quebec Charter or s.7 of the Canadian Charter) can be saved by another provision likewise similar in both (s.9.1. in the Quebec Charter or s.1 of the Canadian Charter) that would justify the measure notwithstanding the violation. ${ }^{16}$

In both cases, this second step involved the application of what is known as the "Oakes test," which specifies the conditions under which a legislative measure found to violate a constitutional provision can be saved according to a higher-order constitutional provision. To meet this test, it must be demonstrated that the objective of the legislation is pressing and substantial, and that the means to attain this legislative end are reasonable and demonstrably justifiable in a free and democratic society. ${ }^{17}$ There must be at least a rational connection between the measure and the purpose of the legislation.

The objective of the legislation was therefore of crucial importance to the legal argument, as that argument was bound to follow the path of analysis prescribed by the Oakes test. One might have expected the Court to devote some considerable care to discerning this objective. Remarkably, although it is apparent that the Minority and the Majority construed the objective differently, and that disagreement about it was divisive and decisive, the difference of opinion about it was never made explicit in the Court as a point of contention.

\footnotetext{
14 As shorthand for McLachlan, C.J., and Major J., Bastarche J. concurring, we write "McLachlan C.J. et al." and for Binnie and LeBel JJ., Fish J. concurring, we write "Binnie J. et al." We use the term "Majority" in the singular to indicate an overlapping consensus among the two judgments that, combined, constitute the Majority.

15 Much of the discussion establishing a violation of Charter rights centred on waiting lists and the risk to life, inviolability, and security of the person that attends sometimes quite lengthy ones. McLachlan et al. (Chaoulli, para. 124) sum up the conclusion at this stage of the argument as follows: "We conclude, based on the evidence, that prohibiting health insurance that would permit ordinary Canadians to access health care, in circumstances where the government is failing to deliver health care in a reasonable manner, thereby increasing the risk of complications and death, interferes with life and security of the person as protected by s. 7 of the Charter."

16 The situation is a little more complicated than this because s. 7 of the Canadian Charter has an additional provision that involves consideration of whether a violated right is consistent with "principles of fundamental justice."

17 This test has been adopted by convention from the case of $\boldsymbol{R}$. $\boldsymbol{v}$ Oakes. Deschamps J. outlines this test at para 48.
} 
In its analysis, the Majority construed the objective of the legislation as being to preserve the quality or integrity of the publicly funded system. ${ }^{18}$ The purpose thus identified, the pivotal question was reduced, essentially, to whether removal of the prohibition against private insurance would cause a loss of quality to the publicly funded system.

The Quebec government's case for the prohibition relied heavily upon expert opinion and evidence about this empirical question, which was presented initially at the trial court. Various arguments had been put forward to the effect that private insurance would harm the public system: the emergence of a private system would diminish political support for maintaining the level of resources in the public health care system, as the rich and influential exited to pay privately and lost interest in supporting the public system; physicians would exit the public system, lured by profit; resources would be diverted from the public to the private sector; the private system would leave very sick patients to the public system, and so on. ${ }^{19}$

The lower courts had been sympathetic to these arguments and to the evidence presented for them. At the Supreme Court, however, the Majority was not convinced. McLachlin C.J. et al. characterized the arguments for and against the prohibition on private health insurance as "competing but unproven 'common sense' arguments, amounting to little more than assertions of belief" (Chaoulli, para. 137). The Majority found the opinion and evidence that the prohibition was necessary to preserve the public health care system to be insufficient. ${ }^{20}$ The prohibition, having been found to violate protected rights, failed the Oakes test requirement that there be a rational connection between the purpose of a piece of legislation and such measures as the legislation might specify to achieve this purpose, and thus could not be saved by s.1. of the Charter.

18 Deschamps J. tends to speak of this objective in terms of "integrity," McLachlan et al. of "quality." The difference in terminology comes to the same thing, as the objective is read by either in terms of "preserving the public plan," as Deschamps puts it (Chaoulli, para. 56). Either way, the issue reduces to whether private insurance would diminish the publicly funded system. Binnie J. et al. work from the same framework in accepting the "practical argument" they attribute to the government that private insurance "would have a harmful effect on the public system" (para. 238). To capture the idea here, common to all three opinions, we use the term "quality" throughout the paper, the contentious issue being whether private insurance would reduce the quality of the public system.

19

Deschamps J. summarizes these arguments beginning at para. 63. For an excellent discussion of the purported externalities of private insurance on a publicly financed health care system and an assessment of their empirical validity, see Sherry A. Glied, "Universal Public Health Insurance and Private Coverage: Externalities in Health Care Consumption," Canadian Public Policy 34 (3, 2008): 345-357.

${ }^{20}$ McLachlan et al. conclude as follows: "When we look to the evidence rather than to assumptions, the connection between prohibiting private insurance and maintaining quality public health care vanishes. The evidence before us establishes that where the public system fails to deliver adequate care, the denial of private insurance subjects people to long waiting lists and negatively affects their health and security of the person. The government contends that this is necessary in order to preserve the public health system. The evidence, however, belies that contention." (Chaoulli, para. 152.) There are good reasons for challenging how the Majority handled the assessment of empirical evidence relative to its finding. For a discussion of the issues, see various essays in Access to Care, Access to Justice: The Legal Debate Over Private Health Insurance in Canada, edited by C. Flood, K. Roach, and L. Sossin (Toronto: University of Toronto Press, 2005), including M. Barer, "Experts and Evidence: New Challenges in Knowledge Translation"; S. Choudhry, "Worse than Lochner;" C. Flood, M. Stabile, and S. Kontic, "Finding Health Policy "Arbitrary': The Evidence on Waiting, Dying, and Two-Tier Systems;" H. Stewart, "Implications of Chaoulli for Fact Finding in Constitutional Cases"; and C.J. Wright, "Different Interpretations of 'Evidence' and Implications for the Canadian Healthcare System." In the same volume, however, K. Roach ("The Courts and Medicare: Too Much or Too Little Judicial Activism?") misrepresents the matter in claiming that the Court "relied on a controversial prediction that eliminating private insurance would improve the public system" (p. 185). In fact, the Majority went no further than finding that the evidence that private insurance was necessary to preserve the public system was insufficient, which is a different and considerably less bold proposition. The Majority's finding regarding the evidence is similarly over stated in Barer ("Experts and Evidence," p. 218); Flood, Stabile, and Kontic ("Finding Health Policy 'Arbitrary'," p. 299); and T. Sullivan et al., "A Just Measure of Patience: Managing Access to Cancer Services after Chaoulli" (in the same volume, p. 455). 


\section{The Minority Account of the Objective of the Legislation}

The Minority did accept the opinion and evidence that the removal of the prohibition would diminish the quality of the publicly funded system and therefore was rationally connected to the objective of the legislation. On this point, the disagreement between the Minority and the Majority was essentially an empirical one concerning what the expert opinion and empirical evidence demonstrated. However, the Minority did not base its case solely on this line of argument. In addition to construing the purpose of the impugned legislation in practical terms of preserving the quality of the public system (and disagreeing with the Majority about the hypothesized effects of private insurance on the public system), the Minority also construed the purpose in principle, in terms of ensuring equality of access to medically necessary services throughout Quebec society. ${ }^{21}$

With respect to equality as grounds for prohibiting private insurance, at least as the Minority conceived equality, the empirical question of whether private insurance would undermine the public system is beside the point. Regardless of what its impact on the public system might be - whether positive, negative, or neutral — private insurance, in principle, undermines the equality purpose. The very fact that some persons would be able to access health services parallel to those in the publicly funded system undermines what the Minority took to be the equality objective of the legislation. In this line of argument, the disagreement between the Minority and Majority was not an empirical issue about evidence but an interpretive issue concerning the purpose of the legislation, and, as we will discuss later, concerning two different accounts of equality.

Although on several points each side explicitly addressed opinions put forward by the other, on the critical interpretive issue about the purpose of the legislation the difference of opinion was not thematized. The Majority did not directly dispute the Minority construal of the purpose in terms of equality. If the Minority interpretation of the purpose has merit, the fact is that its interpretation was not shared by the Majority and did not prevail.

$\overline{21}$ Binnie J. et al. distinguish a "practical" and an "in principle" objective of the legislation at para. 174: "as a matter of principle health care should be based on need, not wealth, and as a matter of practicality the provinces judge that the growth of the private sector will undermine the strength of the public sector." See also para 240: "In practical terms, Quebec bases the prohibition on the view that private insurance, and a consequent major expansion of private health services, would have a harmful effect on the public system." They invoke the 'in principle' argument at least three times, most elaborately at para. 181: "it cannot be contested that as a matter of principle, access to private health care based on wealth rather than need contradicts one of the key social policy objectives expressed in the Canada Health Act. The state has established its interest in promoting the equal treatment of its citizens in terms of health care" [italics and underscoring in the original]. 


\section{Values at Work Behind the Scenes in the Supreme Court?}

The Supreme Court's decision on the legal question has been interpreted as if it were a decision on the normative policy question illicitly driven by ideology and values. Choudhry, who associates the decision with "economic libertarianism," stops short of accusing the Majority of class bias in the way it processed the expert testimony and evidence, but adds that the "optics are bad." 22 Marmor is considerably less guarded in asserting suggesting that the Majority had come to its conclusion even before it undertook its analysis. ${ }^{23}$ Hutchinson claims that the decision "confirms that the Charter has allowed the political right to hijack democracy in the name of constitutional justice." ${ }^{24}$ He claims that the Court not only "barged into the political fray" but in doing so took a "decidedly partial stance in the debate over health care." 25 Petter, who explicitly charges that the "path trod by Chaoulli is ideological,"26 is even bolder in his claims, asserting that the decision discloses the "'liberal legalism' not just of the Charter but also of the four justices in the Majority."27

These sorts of claims about values in play in the Court leap beyond the logic of the legally decisive disagreements as they were expressed under the constraints of legal argument. The legal issue in the Court certainly did not turn on a difference of values between the Minority and the Majority, the one side favouring liberty and the other equality. Rather, in the first instance, and not thematized in the Court, there was an implicit disagreement about the objective of the legislation (and about equality). Subordinate to that, there was an explicit disagreement, thematized as such in the Court, about the empirical evidence and opinion concerning the impact of private insurance on the publicly funded system.

To be sure, liberty was an important value for Chaoulli and Zeliotis. ${ }^{28}$ But none of the Justices considered the liberty grounds in their argumentation, except to rule it out of court. ${ }^{29}$ Likewise the Minority (and to a much lesser extent the Majority) referenced the idea of equality in its argumentation. However, it did so in the context of discerning the objective of the legislation and in interpreting that objective. That was the only foothold the notion of equality had in its argument. ${ }^{30}$

22 Choudhry, "Worse than Lochner," p. 95.

23 T.R. Marmor, "Canada's Supreme Court and Its National Health Insurance Program; Evaluating the Landmark Chaoulli Decision from a Comparative Perspective," Osgoode Hall Law Journal 44 (311, 2006): 1-11.

A. Hutchinson, "Condition Critical: The Constitution and Health Care," in Access to Care, Access to Justice: The Legal Debate Over Private Health Insurance in Canada, edited by C. Flood, K. Roach, and L. Sossin (Toronto: University of Toronto Press, 2005), p. 94.

25 Ibid., p. 104.

26 A. Petter, "Wealthcare: The Politics of the Charter Re-visited," in Access to Care, Access to Justice: The Legal Debate Over Private Health Insurance in Canada, edited by C. Flood, K. Roach, and L. Sossin (Toronto: University of Toronto Press, 2005), p. 120.

27 Ibid. p. 128. Numerous other examples could be provided. Sossin's claim that Hutchinson and Petter reduce the Court's politics in Chaoulli to "a simple knee-jerk ideological equation" may be insufficiently nuanced; see L. Sossin, "Towards a Two-Tier Constitution? The Poverty of Health Rights," in Access to Care, Access to Justice: The Legal Debate Over Private Health Insurance in Canada, edited by C. Flood, K. Roach, and L. Sossin (Toronto: University of Toronto Press, 2005), p. 176.

28 See Hutchinson ("Condition Critical," p. 104) for the ideological positions of Chaoulli and Zeliotis.

29 Choudhry notes that attempts to argue that the protection of "liberty" in s. 7 of the Charter comprehends freedom of contract have been "consistently rejected by the Courts" ("Worse than Lochner," p. 88). Chaoulli would not have been surprised that, as Choudhry points out, his attempt to argue his case on this ground "was unanimously rejected by the Court" (p. 89).

30 S. 15 of the Canadian Charter explicitly addresses equality but that section was not engaged in Chaoulli. 
To underscore these things is not to say that the legal argument or the weighing of evidence in the Court was not informed by competing ideologies or values positions that were not, and by right could not be, explicitly engaged in the legal reasoning. One can conjecture that, behind the empirical disagreement, influencing the weighing of evidence was a fundamental disagreement about values. The ostensibly empirical objection that the removal of the prohibition would undermine the publicly funded system may have been a proxy for an underlying values-based objection grounded in equality. That values-based objection, one might suppose, could not be expressed as such given the constraints on the legal argument, so instead it was surreptitiously voiced in the disagreement about the empirical issue, which issue was legally relevant. And indeed the Minority did argue additionally on grounds of equality, "in principle," as the discernment of the objective of the legislation was legally relevant, and on which grounds the prohibition would stand regardless of its supposed effect on the publicly funded system.

Likewise, one can conjecture that the contrary empirical argument may have been a proxy for an argument grounded in liberty that, as such, could obtain no foothold in the legal argument. Whatever the Majority may have believed in its heart, we know that Zeliotis and Chaoulli certainly supported the removal of the prohibition on grounds of liberty, and quite likely would have even if they believed, contrary to what they argued about the empirical proposition, that private insurance would have an adverse effect on the publicly funded system. ${ }^{31}$

However, whether subterranean ideologies or values differences among the Justices and the various parties that lined up around the case may have influenced the arguments and opinions expressed in the Court is conjecture, and should be qualified as such. What we do know is that the main lines of argument in the Court were not ostensibly about the values of the Justices indeed, the empirical argument was not about values at all. Nonetheless, values did figure, more or less explicitly, and in a fairly constrained way, as the objective of the legislation, and related to that, assumptions about the purpose of the publicly funded system were legally relevant. To this extent, the lines of argument in the Court are helpful for teasing out values of central importance to the policy issue.

Later in the paper, we return to the question of hidden values and ideologies. Before doing so, we want to clarify the values and essential values-based positions engaged in the policy issue. We use the lines of argument in the Court in a literary way to construct these positions, free of the constraints of legal argument and the burden of proving that various parties in the Court in fact held the positions we construct from their arguments.

31 According to Manfredi and Maioni, Chaoulli "changed his tactics slightly" following defeat at the trial court, giving greater emphasis to the empirical argument: "The strategy was to show that parallel private systems did not necessarily jeopardize the public system, as had been argued by experts in the trial proceeding on the basis of U.S. experience" ("The Last Line of Defence for Citizens," p. 6). Counsel for Zeliotis certainly put the question as if accepting the proposition that preserving the quality of the publicly funded system was sacrosanct. Binnie J. et al. (Chaoulli, para. 181) quote Counsel as follows: "May a person use his or her own resources to obtain medical care outside the public system if the public system is unable to provide medical care within an acceptable time and if doing so would not deprive the public system of the resources it needs?" The Quebec government focused its argument in support of the prohibition on the proposition that it was necessary to preserve the public system, so it is only to be expected that Chaoulli would advance a counterargument on this shared ground. Of course, in his factum Chaoulli tried every argument one might imagine, including various liberty arguments. 


\section{VALUE-BASED POSITIONS ON THE POLICY ISSUE}

Leaving the legal issue as such behind us, the question we pose is not whether a prohibition on private insurance for publicly insured services is legal or constitutional but whether it is ethically justifiable. This normative policy issue, as distinct from the legal issue and the empirical issue, turns upon values.

The term "values" is in vogue today in health policy discourse but tends to be used loosely. As we use the term, we mean to identify what someone cares about or prizes in a fundamental way when taking a position on a given policy issue and, in advancing that position, wishes to defend, promote, or at least bring into consideration. ${ }^{32}$ The position taken on the issue as such may or may not explicitly reference values but they can be brought to greater explicitness (singly, in tension with one another, differently weighed, priorized, and so on) if we probe the reasons for the position. Moreover, values are abiding and will therefore inform positioning, more or less predictably, on a range of issues on which they are engaged.

Additionally, the values we will discuss are "ethical," meaning that they pertain to what is believed to be ethically right or good, and are associated with a sense of obligation. It is not just that one holds this or that value as a matter of fact: one believes one ought to hold that value - that the value is right. Finally, in addition to being ethical, the values we will discuss are also political: they concern right and wrong in the matter of government and what government is obliged to do or not to do.

There are important limitations to any attempt to clarify values in play in public controversy. Because values are more or less vague, ambiguous, and subject to interpretation, interpretive work may be needed to discern the values and ranking of values implicit in a given policy position, particularly as people may be confused, ambivalent, or even less than honest about the values underlying their policy positions.

32 In addition to being amorphous, the concept of "value" is essentially contested. Consideration of the philosophical debates about value are beyond the scope of this paper. For reasonably accessible discussions, see B. Bradley, "Two Concepts of Intrinsic Value," Ethical Theory and Moral Practice 9 (2006): 111-130; and D. Alm, "An Argument for Agent-Neutral Value," Ratio 20 (September 2007): 240-263. Our parsing of the concept is in line with the fairly standard account given by Harold: "By 'value' (or 'good' or 'commitment'), I mean the object of a person's valuing: a commitment to a goal, ideal, or principle. Not everything one cares about is a value, but those commitments that one ordinarily takes to be justified, or in need of justification, are. Values are those interests that one not only cares about but where one also endorses or assents to that caring. (So valuing is not identical with mere liking or desiring). Values need not be distinctively moral: some values are aesthetic and some are prudential." See J. Harold, "Between Intrinsic and Extrinsic Value," Journal of Social Philosophy 36 (1, 2005): 85. 
We claim that the private insurance policy issue significantly engages three main values: welfare, equality, and liberty. These values, of course, are subject to interpretation. For example, to hold the welfare value is to hold that government ought to promote the welfare of its citizens in meeting needs. But exactly how far is government obliged to go in ensuring the welfare of its citizens? What needs should government provide for, and to what degree? Equality as a political value means, at least, that government should treat citizens equally. Ought it also to try to engineer material equality among its citizens, and if so, to what extent? Liberty as a political value means, at least, that government should leave individuals free to make decisions about their own good, subject to certain limits. But exactly what limits, and with respect to what range of decisions? Each of the values we have identified has different meanings depending on how the answers to these and other important questions are nuanced. These nuanced differences can be decisive and divisive in policy disputes. We shall see that, for the issue at hand, nuances in the interpretation of equality are critically important and are not carefully distinguished in policy debate about private insurance.

More important, in policy disputes, values - or nuances in the interpretation of a given value - are in tension or conflict. Positions on a policy issue can be distinguished according to how the values in tension are weighed or ranked relative to one another. Indeed, if one does not acknowledge these tensions, the evocation of this or that value is likely to be platitudinous. We distinguish what we take to be three main values-based positions on the issue of private insurance, differentiating them according to how the values in tension are nuanced, priorized, and weighed relative to one another. We call these positions welfare egalitarianism, absolute egalitarianism, and libertarianism.

\section{Welfare Egalitarianism and Absolute Egalitarianism}

As we have seen, numerous experts and the Minority of the Supreme Court of Canada supported the prohibition on private insurance for publicly insured services on the grounds that the ban was necessary to preserve the quality of the publicly funded system. For the sorts of reasons and evidence cited by various experts, they believed that removal of the prohibition would have a negative effect on the integrity of the public health care system. Disagreement about this issue is a disagreement about the facts, and not about values. ${ }^{33}$ However, in disagreeing about the empirical issue, the Minority and the Majority assumed a common ground - namely, preserving the quality or integrity of the publicly funded system. At least implicit in that common ground is a belief about the values of the publicly funded system. In probing these values, we construct a values position we call "welfare egalitarianism." In doing so, we do not assert that either the Majority or Minority held this position; only that they assumed or presupposed this common ground, albeit more or less implicitly, as they discerned the purpose of the impugned legislation and disagreed about the effect of private insurance on the quality of the publicly funded system.

Additionally, the Minority argued that, in principle, the removal of the prohibition would thwart the objective of the legislation and the purpose of the publicly funded system. This is a

\footnotetext{
33 To be precise, the disagreement is about empirical probabilities and predictions, based on such evidence as is available. One could argue that it is, rather, or additionally, a disagreement about risk assessment, in which case our point would be that risk assessment, as distinct from the evaluation of the acceptability of risks, is essentially an empirical matter.
} 
different sort of claim, essentially conceptual or analytic, grounded in a different account of the purpose of the system and the values upon which it is based. From this account, we construct a values position we call "absolute egalitarianism." Again, we do not assert that the Minority held this position; only that, in arguing its case, it assumed or presupposed the value, more or less explicitly.

\section{WELFARE EGALITARIANISM}

Our elaboration of the welfare egalitarian position is limited specifically to welfare and equality in the matters of needed health care services and of outcomes and health status as they presumably correlate with such services. Welfare egalitarianism is not in principle opposed to private insurance. Rather, support or opposition is contingent or dependent on whether private insurance would have the effect of diminishing the quality of the publicly funded system. What is this quality or integrity about which the welfare egalitarian cares? We call it "welfare" — the ability of the system to meet the health needs of Canadians. If we take $X$ to represent the level of quality the system is able to provide without private insurance, would private payment increase $\mathrm{X}$, diminish it, or leave it unchanged? Would private insurance cause it to happen that people dependent on the publicly financed system would be worse off with respect to the quality of the health services available to them $?^{34}$

In its concern about welfare, welfare egalitarianism could be misconstrued as a species of the "utilitarian" position that views the object of public policy to be the maximization of society's total well-being, on the assumption (a dubious one) that the quality of the health system directly correlates with total well-being. However, welfare egalitarianism is, after all, an egalitarian position: equality matters. The utilitarian calculus does not directly consider equality as a concern in how welfare is distributed. ${ }^{35}$

In the Chaoulli Court, everyone agreed that, along with welfare, equality is a fundamental value of the publicly funded system. However, equality is an elastic concept, and there was an important difference in how the Majority and the Minority nuanced it. As we go on to construct the position using the Majority account of the purpose of the publicly funded system as a guide, the welfare egalitarian cares about equality in a restricted sense and scope, as it applies only to access to services provided in and by the publicly funded system. Everyone should have public access to health services to meet their needs, and access to these publicly funded services should be equal. Equality in this limited sense is not threatened or put at issue by private insurance. Even if it were to diminish the quality of the publicly funded services available, private insurance would not necessarily impinge on the equality of access to them within the system.

\footnotetext{
34 We intend the term "welfare" as it relates indirectly to the quality of health care provided in the publicly financed health system, on the assumption that the quality of health care available to people correlates with their welfare or well-being. We do so because Chaoulli is the point of departure for our analysis, and it was quality that was at issue in the Court. The Court used the term "quality" quite loosely, its primary measure being the length of waiting lists. Of course, however one defines or measures quality in the health care system, and even if one links it directly to health outcomes, it does not directly correlate with welfare in a broader sense as including health status. Gains in the quality of the health care system do not necessarily equate to gains in welfare broadly conceived, and much less does equality in access to health services equate to equality of health status.

35 As Hurley explains, more equal distribution outcomes are consistent with utilitarian social welfare maximization if there is a diminishing marginal utility of income property whereby an incremental dollar of resources is valued more by a poor person than a rich person. In this case, transferring resources from the rich to the poor raises overall welfare. See Jeremiah Hurley, "Ethics, Economics, and Public Financing of Health Care," Journal of Medical Ethics 27 (4, 2001): 234-239; and idem, "An Overview of the Normative Economics of the Health Sector," in Handbook of Health Economics, vol. 1, edited by Anthony J. Culyer and Joseph P. Newhouse (New York: Elsevier, 2000).
} 


\section{ABSOLUTE EGALITARIANISM}

The absolute egalitarian objects to private insurance not on contingent, empirical grounds, but in principle. The dominant value here is equality, or a specific interpretation of equality more extensive in scope than that held by welfare egalitarians. For the absolute egalitarian, equality matters not just within the system, but also between the system and what happens outside it, in the private provision of parallel medically necessary services. If equality is understood in this sense - whether private insurance would diminish quality in the publicly funded system - it certainly would increase differential access to medically necessary services, based on ability and willingness to pay. In and of itself, this is inconsistent with equality in the sense the absolute egalitarian cares about, regardless of its impact on the quality of the system. The Minority, in the second line of argument in which it disagreed with the Majority about the purpose of the legislation and the health system, argued from these values grounds.

\section{CONTRASTING WELFARE EGALITARIANISM AND ABSOLUTE EGALITARIANISM}

As we have described the positions so far, the difference between the welfare egalitarian and absolute egalitarian is rooted in a difference about the fundamental values of the publicly funded system, and in particular in different interpretations of the value of equality and in the relative weighting of welfare and equality. ${ }^{36}$

The welfare egalitarian conception of equality can be expressed in a principle to the effect that, for all Canadians, the publicly funded system should provide for fundamental health needs, and do so on equal terms and conditions. The Majority held some such view. Deschamps J., who talks about "quality and equality" as being "inseparable" in relation to the purpose of the Quebec legislation, writes: "The general objective of these statutes is to promote health care of the highest possible quality for all Quebecers regardless of their ability to pay" (Chaoulli, para. 49). She parses the legal question as being whether the prohibition is necessary for achieving the state objective of providing "high quality health care services that are accessible to all residents of Quebec" (para. 57). Equality here connects to the "for all" in the receipt of whatever services it is that the publicly funded system offers. Provided that private insurance would not diminish the ability of the publicly funded system to meet the needs of all Canadians, and that in meeting needs all Canadians are treated equally within the system, private insurance is not objectionable.

\footnotetext{
${ }^{36}$ Remarkably, although the concept of equality is frequently mentioned in the extensive literature on Chaoulli, there has been very little analysis of the term. However, a good discussion of it can be found in C.E. Forget, "Promises, Promises: Setting Boundaries between Private and Public," in Access to Care, Access to Justice: The Legal Debate over Private Health Insurance in Canada, edited by C. Flood, K. Roach, and L. Sossin (Toronto: University of Toronto Press, 2005). His sober assessment of the meaning of equality is worth quoting: "In reality, the notion of equality in our health care system has remarkably narrow meaning. Equal treatment in our system has at most a purely procedural, as opposed to a substantive meaning: individuals should be dealt with according to the same process (albeit with respect for their dignity) without any guarantee that this will translate into equal outcomes" (p. 402). This is how the Majority interpreted equality. Glied finds that, after accounting for differences in health care service use across income groups, Canada's health care system displays no progressivity in terms of transferring resources from high-income to lower-income Canadians; see Sherry A. Glied, "Health Care Financing, Efficiency, and Equity," NBER Working Paper 13881 (Cambridge, MA: National Bureau of Economic Research, March 2008). For a succinct philosophical overview of the concept of equality and associated issues, see S. Gosepath, "Equality," Stanford Enyclopedia of Philosophy; accessed online (15/5/2009) at website http://plato.stanford.edu/entries/equality/.
} 
The absolute egalitarian has a stronger "equality-as-solidarity" principle to the effect that the government should ensure that all Canadians have equal access to medically necessary services to meet their fundamental needs. Binnie J. et al. expressed some such view. ${ }^{37}$ They approvingly quote the trial judge that, "The purpose of the impugned provisions is to guarantee equal and adequate health care for all Quebecers" (Chaoulli, para. 241). They note that "Quebec subscribes to the policy objectives of the Canada Health Act," among which they include "the equal provision of medical services to all residents, regardless of wealth or personal insurability" (para. 236). ${ }^{38}$ In formulating the objective of the legislation as they do, Binnie J. et al. assume a more extensive idea of equality, and one which is essentially at odds with private insurance.

Throughout their judgment, Binnie J. et al. reference Romanow, who appears to hold the extensive view of equality they claim to discern in the purpose of the legislation and in the Canada Health Act. Romanow writes:

Canadians have been clear that they still strongly support the core values on which our health care system is premised - equity, fairness and solidarity. These values are tied to their understanding of citizenship. Canadians consider equal and timely access to medically necessary health care services on the basis of need as a right of citizenship, not a privilege of status or wealth. ${ }^{39}$

In talking about the core values of the system, not only does Romanow omit to mention welfare (for example, as correlated with the quality of the health system), but he speaks specifically of equal access to medically necessary services, and not just to publicly funded ones. If parallel medically necessary services were also available privately through private insurance, outside the publicly funded system, it would be analytically true - true "in principle" as the Minority put it - that access to those services on the basis of ability to pay is incompatible with equality. It would be so regardless of the impact on welfare in the system, and even if private payment had the effect of increasing utility and preserving equality of access to publicly funded services.

37 We are keeping our account of the difference between the Minority and Majority interpretation of equality fairly literal. It should be noted, however, that, for the Minority, equality, in addition to having a much broader extension than the Majority gives it, appears also to have symbolic meaning related to, or standing for, something like solidarity or social well-being, and connected to Canadian identity.

38 Yeo and Lucock point out that no such statement of objective appears in the Canada Health Act; see Michael Yeo and Carole Lucock, "Quality v. Equality: The Divided Court in Chaoulli v. Quebec," Health Law Journal 14 (2006, 142). S. 3 of the Canada Health Act states plainly states that "the primary objective of health care policy is to protect, promote and restore the physical and mental well-being of residents of Canada and to facilitate reasonable access to health services without financial or other barriers." The Act requires comprehensive public payment for "medically necessary" services with universal coverage and without financial barriers to access. At the risk of oversimplification, the point of public funding, as the Majority puts it, is to ensure that all Canadians, regardless of their ability to pay and without great sacrifice, can obtain the health care that they need. Deschamps J., noting that the Act tends to evoke strong emotions, accuses the Minority of reacting emotionally in its interpretation. At para. 16, she writes: "The tone adopted by my colleagues Binnie and LeBel JJ. is indicative of this type of emotional reaction. It leads them to characterize the debate as pitting rich against poor when the case is really about determining whether a specific measure is justified under either the Quebec Charter or the Canadian Charter. I believe that it is essential to take a step back and consider these various reactions objectively. The Canada Health Act does not prohibit private health care services, nor does it provide benchmarks for the length of waiting times that might be regarded as consistent with the principles it lays down, and in particular with the principle of real accessibility." For a sober discussion of what is and is not permitted under the Canada Health Act, see Boychuk, "The Regulation of Private Health Funding and Insurance in Alberta."

39 Romanow, Building on Values, p. xvi. 
In sum, there is an important difference between the principle that all Canadians should have access to necessary health care services provided by a publicly funded system (with equal access to those services) and the principle that all Canadians should have equal access to needed health services. ${ }^{40}$ Private insurance is in principle inconsistent with the latter, but only contingently inconsistent with the former - that is, if it would reduce the quality of the publicly funded system.

The welfare egalitarian and the absolute egalitarian positions therefore differ in principle in how they construe equality. To crystallize this difference, it is useful to compare possible positions on what Binnie J. et al. call the "practical" ground as regards the impact of private insurance on the quality of the publicly funded system. Logically, there are three possibilities concerning this impact: private insurance would diminish the quality of the publicly funded system, it would increase it, or it would have no effect. The difference between the welfare egalitarian and the absolute egalitarian comes into sharp focus if we probe and test their values with reference to each of these scenarios.

If private insurance had an adverse effect on the publicly funded system, both equality, in the sense the absolute egalitarian cares about, and welfare would be negated. The welfare egalitarian and the absolute egalitarian alike would oppose it, albeit for different value reasons, and the welfare egalitarian only contingently. Moreover, even if private insurance would have a negative effect, prohibiting it would not be the only way to address the welfare egalitarian's chief concern and to prevent its negative effects on welfare in the publicly funded system. As Glied explains, a corrective Pigouvian tax on private insurance purchases that achieves the efficient (non-zero) level of such purchases could achieve the same effect as a prohibition, and without the welfare loss of frustrated need and demand. This option would not address the concerns of the absolute egalitarian, since the adverse effect of private insurance on equality between the system and its outside would remain the same. ${ }^{41}$

Suppose, however, that private insurance, without any corrective, would have a neutral effect on welfare in the publicly funded system. In this scenario, welfare in the publicly funded system would not be affected. However, it would be increased (presumably) for those willing and able to pay for private insurance. To prohibit private insurance under these conditions would be to negate increased welfare (not to mention liberty, which we leave out of account until later) for some Canadians in the name of equality of all.

40 The conflation of these principles is not uncommon. For example, in their study of "national values," Marmor, Okma, and Latham claim that Canada's medicare system is based on what they call "egalitarian values" ("National Values, Institutions and Health Policies, p. 6). But what exactly do they mean by this? Writing that "Canada's core national values have been well expressed by Michael Ignatieff," they quote him to say, "We [Canadians] think that public taxation should provide for health care and that it is wrong for decent medical care to depend on the size of our bank balances" (p. 2). Note that nothing in what Ignatieff says is incompatible with private insurance or even private payment for health services, provided that it would not adversely impinge on the ability of government to provide "decent medical care." His position is compatible with what we call welfare egalitarianism, not absolute egalitarianism. Yet Marmor, Okama, and Latham invoke these supposedly "core national values," taking Ignatieff's statement as a paradigm expression of them, to rule out private payment and private insurance (p. 16). This vagueness about values, and the slide or equivocation between two critically different conceptions of egalitarianism, is strikingly ironic given that the authors ' "aim has been to note how little explicit debate about 'values' has taken place in reviews of Medicare and how difficult it is to identify unambiguously the value differences that some of the proposals for change actually reveal" (p. 7).

41 Glied, "Universal Public Health Insurance and Private Coverage." 
G.A. Cohen discusses such a scenario and how he thinks egalitarians would respond. He is not specifically talking about private insurance, but the projected welfare impacts of his example are the same, and we take the liberty of imagining it to be at issue:

And when their critics charge them with being willing, for the sake of equality, to grind everyone down to the level of the worst off, or even lower, they do not say, in response: well, yes, let us grind down if necessary, but let us achieve equality on a higher plane if that is possible. Instead, what they say is somewhat evasive, at the level of principle; they just deny that it is necessary, for the sake of achieving equality, to move to a condition in which some are worse off and none are better off than now. ${ }^{42}$

The description of this scenario in terms of a willingness to "level down" suggests ignoble motives such as resentment. An evasive response would be understandable, given the harshness of the tradeoff Cohen forces. However, if the egalitarian, for whatever reasons, does not believe that the distribution of utilities under private insurance would in fact be as the scenario projects - those in the publicly funded no worse off, but those having private insurance better off - he or she must admit that it is at least possible. We insist on that possibility, as Cohen does, to test how strongly the egalitarian holds the equality value relative to welfare. Cohen adds:

Were they more reflective, they might add that, if levelling down were necessary, then equality would lose its appeal. Either it would make the badly off worse off still, in frustration of the original egalitarian purpose, or it would make the badly off no better off, while others are made worse off to no evident purpose. $^{43}$

The egalitarian interlocutor Cohen projects, if pushed to suppose that equality-preserving measures would leave at least some people worse off and others no better off, would see no "evident purpose." In the language of the Chaoulli Majority decision, a law mandating such equality-preserving measures would be "arbitrary."

In our terms, this is an indication that Cohen's egalitarian, if-push-comes-to-shove is not an absolute egalitarian but a welfare egalitarian. Indeed, the welfare egalitarian would see no "evident purpose" in prohibiting private insurance if the prohibition would increase welfare for those with private insurance but leave those within the publicly funded system no worse off. For the absolute egalitarian, however, there would be an evident purpose - namely, to promote equality in the extensive sense, albeit at the price of the levelling down entailed by this scenario.

42 G.A. Cohen, "Incentives, Inequality and Community," in The Tanner Lectures on Human Values, vol. 13, edited by Grethe B. Peterson (Salt Lake City: University of Utah Press, 1992), pp. 267-268.

43 Ibid 
Welfare egalitarianism, as we characterize it, taking the Majority position in the Court as our guide, subscribes to the Pareto principle: so long as the gains by one person do not make anyone else worse off, such inequality as this entails may be justified. This position is not inconsistent with the values inherent in Rawls's theory of justice and his famous "difference principle." 44 Rawls would have us evaluate resource distributions with primary reference to the least advantaged members of society; inequalities are justified to the extent they have the effect of increasing the welfare of those who are least well off. In the context of the issue at hand, the "least well off" would be all Canadians who (equally) are entitled to receive health care through the publicly funded system.

The application of the difference principle to our scenario is not straightforward. As Jeremiah Hurley points out, whereas "Rawls' difference principle would permit a deviation from an equal distribution of health if it improved the health and wellbeing of the least advantaged members of society; it is silent on the characteristics of the distribution above this minimum level." ${ }^{45}$ As we characterize the welfare egalitarian, and as Cohen does, he or she takes "the difference principle in its more generous form, in which it allows inequalities that do not help but also do not hurt the worst off." ${ }^{46}$

Absolute egalitarians are not primarily concerned with welfare as such but as subordinated to equality - comparative welfare, welfare relative to others. And it is upon this point that absolute egalitarianism is most vulnerable to criticism. Walter Glannon, for example, claims that "We should give priority to the claims of need of the worse off because of how they fare with respect to an absolute decent minimum of health care, not because of how they compare with the better off. Assuming that people have reached this basic level, they would have no moral claim to receive the same health care as those who can purchase additional health care above that level." ${ }^{47}$ Harry Frankfurt $(1987,34)$ likewise argues that " $[t]$ he fundamental error of egalitarianism lies in supposing that it is morally important whether one person has less than another regardless of how much either of them has." 48

44 John Rawls, "Justice as Fairness: Political not Metaphysical," Philosophy and Public Affairs 14 (3, 1985): 227.

45 Hurley, "Ethics, Economics, and Public Financing of Health Care," 235.

46 Cohen, "Incentives, Inequality and Community," p. 266.

47 Walter Glannon, Biomedical Ethics (Oxford: Oxford University Press, 2005), p. 162. There is lots of room for disagreement among welfare egalitarians about what the "decent minimum" is. In the Canadian context, the way the concept of "medical necessity" is deployed pre-empts explicit argument about the decent minimum, as if value judgments were not being made about the quality and availability of the services in the publicly funded system. The belief that everyone gets (or is supposed to get) what is "medically necessary" masks the issue of what the decent minimum is or should be. Alternatively, the decent minimum simply is whatever is deemed medically necessary, the concept of "medical necessity" being elastic and vague enough to accommodate a range of value judgments. According the Canada Health Act requirement for comprehensiveness, medicare must finance all "medically necessary" physician and hospital services such that there are no financial barriers to access for these services (Boychuk, "The Regulation of Private Health Funding and Insurance in Alberta," p. 12). However, as Robert Evans points out, the test of medical necessity of a service has been "that a properly licensed physician was willing to provide it and a patient to accept it"; Robert G. Evans, "Canada: The Real Issues," in The Politics of Health Care

Reform: Lessons from the Past, Prospects for the Future, edited by James A. Morone and Gary S. Belkin (Durham, NC: Duke University Press, 1994), p. 468. Presumably, services not funded under medicare dentistry, prescription drugs out of hospitals, and services of non-physicians are supposed not to be "medically necessary." An alternative test for the medical necessity of services would be to consider whether a service is effective, or perhaps even cost effective (Hurley, "An Overview of the Normative Economics of the Health Sector," p. 91). Evans claims that many services provided by physicians, or during stays in hospital, have no demonstrable health benefit. In the absence of a health benefit from the service, it is not medically necessary and could be de-insured (removed from medicare coverage); see Evans, "Canada," p. 468.

48 Harry Frankfurt, "Equality as a Moral Ideal," Ethics 98 (1987): 34. 
In response to these sorts of criticisms, it is important to point out that we limit our description of the absolute egalitarian position to generic formal terms, with respect only to the tradeoffs he or she is prepared to make in the name of equality; we do not ascribe to this position a particular moral psychology. One can characterize the position in terms less vulnerable to the kinds of criticism referenced above. For example, it could be elaborated such that what matters is not just equality as concerns the literal effect of health care services on personal well-being, but equality as essentially tied to some other, more intangible value along the lines of solidarity or social well-being. ${ }^{49}$ Communitarians, for example, might reference here the idea of the common good, or a sense of common destiny across society, tied symbolically to equality in the material sense, but not reducible to it. ${ }^{50}$ Along similar lines, one could elaborate the absolute egalitarian position in terms of a broader conception of welfare than the welfare egalitarian holds, linked to equality, to mean something like "social well-being." ${ }^{51}$ One might say that, even if private insurance literally had no adverse impact on welfare - that no one in the system was worse off in consequence of it - social well-being might nonetheless be diminished by allowing it. Moreover, if disallowing private insurance meant that welfare in the literal sense would be increased, social well-being might very well be decreased.

49 Nielsen considers a scenario similar to the one we pose and posits that the inequality, even in the face of increased welfare, is inconsistent with what he calls the "primary social good of self-respect"; see Kai Nielsen, "Class and Justice," in Justice and Economic Distribution, edited by J.A. Arthur and William H. Shaw (Englewood Cliffs, N.J.: Prentice-Hall, 1978), p. 232. He supposes that, "by the very existence of this extensive disparity" people who would be better off than they otherwise would be under conditions of equality would have "their moral persons assaulted and their self-respect damaged" (p. 230). "This is true," he adds, "even if in terms of income and wealth the inequality of opportunity will make them better off, and in that sense, enhance their opportunities more than they otherwise would be enhanced."

50 Binnie J. et al. (Chaoulli, para. 223) also adduce "collective responsibility" as a value of reference. For an excellent discussion of the concept of "general well-being" as linked to the "classical notion of the common good," see J.F. Gaudreault-Desbiens and C.M. Panaccio, "Chaoulli and Quebec's Charter of Human Rights and Freedoms: The Ambiguities of Distinctness," in Access to Care, Access to Justice: The Legal Debate Over Private Health Insurance in Canada, edited by C. Flood, K. Roach, and L. Sossin (Toronto: University of Toronto Press, 2005). With specific reference to Chaoulli, they write that "a reasonably efficient single tier public medicare system which treats everyone equally on the basis of need is an intricate part of a society's search for justice and the common good, as it is grounded the values of community, solidarity, health, life and equality/fairness, all to be enjoyed in common" (p. 43).

51 Indeed, the health system has symbolic significance beyond how it literally or empirically affects material wellbeing. In a very interesting discussion, Gaudreault-Desbiens and Panaccio claim that this is not so in Quebec: Quebecers, contrasted with other Canadians, tend to view the health system more in "functional" than in "symbolic" terms ("Chaoulli and Quebec's Charter of Human Rights and Freedoms, p. 47). Suffice to say that the Majority did not allow symbolic considerations to enter into consideration, except to chastise the Minority for doing so. 
We leave it an open question how the absolute egalitarian might parse the value of equality or welfare beyond or in addition to the availability and distribution of health care services. The key thing is that, whatever else equality might mean or represent, it encompasses equality as concerns access to health services across society, and not just within the publicly funded system. This is what is at issue in the scenario we have posed, and faced with the tradeoff the response will be the same. The welfare egalitarian who objects to the prohibition on the grounds that it would have an adverse effect on welfare in the publicly funded system would drop the objection if the evidence showed that its effect would be neutral. The absolute egalitarian, by contrast, would object even under these conditions, on grounds of equality at least. ${ }^{52}$ The government has an obligation not just to ensure equality within the publicly funded system, but also to use it powers to prevent inequality from arising outside of that system, whether because this inequality as such is objectionable or because it would undermine some related value to which it is essentially or symbolically tied.

The contrast between the welfare and the absolute egalitarian is even sharper if we consider the third possible scenario, in which private insurance would have the effect of increasing welfare in the publicly funded system, making everyone better off, albeit increasing inequality as between being inside and outside the system. This scenario fits Rawls's difference principle exactly and without need for extrapolation. In this scenario, the welfare egalitarian would have to drop his or her objection to private insurance and, indeed, support it. For the absolute egalitarian, however, equality, in the sense that he or she cares about it, is so important that prohibiting private insurance is justifiable even if it would decrease the level of welfare in the publicly funded system and make everyone worse off. This is because, comparatively speaking, private insurance would increase inequality, which would compromise social well-being or some such more intangible value. Either way, for the absolute egalitarian, the rather stark tradeoff is that it would be better to accept less quality for all Canadians in the name of equality and what it stands for. ${ }^{53}$ Indeed, the absolute egalitarian would oppose all three empirical answers we have proposed to the question of how private insurance would affect the quality of the publicly funded system. Thus, for the absolute egalitarian, the empirical question is not decisive at all. It is, however, for the welfare egalitarian, whose position on private insurance turns on the answer, which bears on the value he or she cares most about: welfare. That is, the position of the welfare egalitarian turns on contingent empirical grounds whereas the absolute egalitarian objects to private insurance for essential reasons, in principle, and regardless of what effect it would have on welfare in the publicly funded system.

\footnotetext{
52 For evidence and argument suggesting that inequality as such correlates with health, see R. Wilkinson, The Impact of Inequality: How to Make Sick Societies Healthier (New York: The New Press, 2005). People in inferior positions $q u a$ equality will tend to have inferior health status in one way or another caused by the inequality as such. The position that we should reduce inequality in society in order to promote welfare is essentially welfare egalitarian, since welfare is the dominant value, and equality is only instrumental.

53 If we interpret equality in the sense that the absolute egalitarian interprets it, we would have to say that the welfare egalitarian is prepared to sacrifice equality for welfare in the publicly funded system; the absolute egalitarian, by contrast, is prepared to sacrifice welfare in the publicly funded system for equality. However, if we interpret equality in the more limited sense of the welfare egalitarian, no such sacrifice is necessary because equality is not engaged.
} 


\section{Libertarianism}

The two positions we have described were constructed with reference to lines of disagreement in the Chaoulli Court. From the explicit disagreement between the Majority and the Minority about the evidence pertaining to the probable impact of private insurance on the publicly funded system, we constructed the values-based position of welfare egalitarianism. In disagreeing on the empirical issue, the Minority and Majority assumed at least this commonvalues ground: preserving the quality or integrity of the publicly funded system.

From the additional disagreement between the Majority and the Minority about the objective of the impugned legislation and, related to that, about the purpose of the publicly funded system and about the sense of equality, we constructed the position of absolute egalitarianism and contrasted that position with welfare egalitarianism.

We were able to construct these two positions using lines of argument in the Court because the values in tension or in conflict between them, welfare and equality, had some foothold in the legal argument. Following the Oakes test, it was necessary to identify the objective of the impugned legislation and, related to that, the purpose of the publicly funded system. Welfare and equality (in one or other of the two senses we have distinguished) figured in that purpose as it was identified (and identified differently) by the Majority and the Minority.

However, in addition to welfare and equality (however nuanced), there is another significant value engaged by the policy issue of whether governments should prohibit private insurance private, and that value is liberty. The values-based position that gives prominence to this value we call "libertarianism."

In the Court, no one argued that the purpose of the publicly funded system comprehends the value of liberty. Although the Court did not entertain arguments against the prohibition that appealed to liberty, public policy debate is not thus constrained. ${ }^{54}$ Leaving aside the legal question, the value of liberty is surely engaged by, and at stake in, the question of whether government should prohibit private insurance. For government to prohibit private insurance, regardless of its effect on welfare, is an infringement of liberty and, if explicitness matters, should be acknowledged as such. Whether this infringement is justified is a different question that engages not just welfare and equality but also liberty.

To characterize the libertarian position, we pose the following hypothetical question: If the facts indicated that private insurance would diminish the quality or integrity of the publicly funded system, would this be reason enough for the government to prohibit it? On values grounds, welfare egalitarians would answer in the affirmative. If, as the question would have us assume for the purpose of argument, welfare and liberty were in conflict, it would be justifiable to negate or sacrifice liberty for welfare. On values grounds, absolute egalitarians would likewise answer in the affirmative: regardless of impact, private insurance would negate equality, and in a conflict between equality and liberty, the absolute egalitarian would sacrifice liberty. ${ }^{55}$

\footnotetext{
54 Although s. 7 guarantees "life, liberty and security of the person," the Court did not consider liberty as such.

55 It may be that this curtailment is not all that significant in practice, since people who have the means can always travel to another jurisdiction to obtain the service and since 2008 private insurance has been available for this through Calgary-based Acure Health Corp. Regardless, in principle, this clashes with a libertarian view of the state and of the relationship between the state and its citizenry.
} 
The libertarian, by contrast, would answer the question in the negative: however much the libertarian cares about equality (however nuanced), he or she cares more about liberty. One might suppose that the libertarian would have reservations about how extensively the government should be involved in meeting the health welfare needs of its citizens since it must do so out of tax revenues, the tax burden increasing the more extensively it seeks to meet those needs ${ }^{56}$ Nothing in our analysis depends on that. The essential thing is that welfare is not important enough to accept the more significant limitation of freedom that is entailed by a prohibition on private insurance. Even if allowing private insurance would have the effect of decreasing the welfare in the system, welfare is not a weighty enough consideration to justify sacrificing the liberty of citizens to spend their own money to safeguard their health. And neither is equality in the extensive sense. Liberty matters more than welfare, and on this point the libertarian position is at odds with the welfare egalitarian position. Liberty also matters more than equality - at least in the extensive sense, the only sense engaged by the private insurance issue - and on this point libertarianism is at odds with absolute egalitarianism. Whether or to what extent the libertarian cares about these other values and believes that government has obligations in connection with each of them, he or she does not care about them enough to sacrifice liberty for them.

In describing the welfare egalitarian and absolute egalitarian positions, we initially left liberty out of consideration. We did so because we used the lines of argument in the Court as our guide, and liberty had no play in them. We leave it an open question how or to what extent liberty also matters for persons holding either of these positions. However much liberty might matter to the absolute egalitarian, he or she would sacrifice it for equality in the extensive sense. And however much it might matter to the welfare egalitarian, he or she would sacrifice it for welfare, at least in the publicly funded system.

However, if welfare were not at issue - if private insurance would not have an adverse effect on welfare - there would be a conflict between equality, in the extensive sense, and liberty. If we took liberally the Majority in the Court as our guide, we might suppose that, under these conditions - in which the values that he or she principally cares about are not engaged - the welfare egalitarian also would care enough about liberty to believe that its infringement, entailed by a prohibition on private insurance, cannot be justified in the name of equality in the extensive sense. Regardless, the essential thing is that, if liberty matters, for the welfare egalitarian it matters less than welfare, and for the absolute egalitarian less than equality in the extensive sense.

56 Of course, there are libertarians who do not support the publicly funded system at all — believing, for example, that the state should not be the health care insurer/provider. Obviously, for anyone opposed in principle to state provision of health care, infringement of freedom by the state in order to protect the state system or to protect equality is not acceptable. This view is not in play in the private insurance issue in Canada. 


\section{MAKING VALUES EXPLICIT}

Should Canadian governments prohibit private insurance for medically necessary services parallel to ones provided in the publicly funded system? We have argued that this public policy issue engages three main values in tension and conflict: welfare, equality, and liberty. The three main value positions we have distinguished assess the relative importance of these values, and the government's obligations in relation to them, differently.

We cannot say with any certainty how prevalent these positions are in Canadian society because, in so much of the discussion that evokes the language of values, the tension among values and the need for tradeoffs is not made explicit. Moreover, much public discussion about private insurance following Chaoulli, like the discussion that took place in the Court, has occurred as if it turned decisively on the empirical issue, on the common-values ground of welfare egalitarianism, and among persons holding only welfare egalitarian values but were merely disputing the evidence. Certainly, if the argument were only about that empirical issue, there would not be a policy issue at all about private insurance, since everyone would be in agreement about the values engaged and how they matter relative to one another.

We do not take a position on that empirical issue, but we are aware that many people who line up on the policy issue as if it turned on the empirical side issue have strong beliefs about what the evidence shows and does not show. Many who hold one or the other belief about the empirical issue are unlikely to be persuaded otherwise. That is why we pose hypothetical questions, to test whether or to what extent the answers really are decisive in guiding a policy response, to bring out underlying values that, regardless of the answer, may be decisively important in taking a position on the policy issue (and perhaps additionally, and illicitly, on the empirical issue). Indeed, as we indicated earlier, some policy commentators who supported the prohibition, convinced that the empirical evidence demonstrated that its removal would affect welfare adversely, conjectured that the Majority was ideologically driven in finding this evidence to be inconclusive. Did the value of liberty surreptitiously weigh in the Majority's assessment of the evidence and motivate it, illicitly, to find otherwise than what, on strictly empirical grounds, the evidence conclusively showed? This is, of course, possible. And if it were true, this would not be surprising. However, if one admits this possibility, one must also admit that it is possible, as Deschamps J. at least implied, that the contrary finding of the Minority - and of most of the experts considered in the Court, and of the policy commentators who suspect the Majority of being ideologically driven - was likewise ideologically driven.

It is noteworthy that such recriminations from either position proceed within a common assumption that the issue concerning the effect of private insurance is an empirical one and, as such, should be determined narrowly on strictly empirical or scientific grounds. Values have no rightful place in its adjudication - or, rather, the only values that rightfully should guide such adjudication are those of scientific enquiry: openness to the evidence and willingness to change one's position if the facts prove to be otherwise than one supposes or even wishes them to be. We do not side with either position with respect to these charges of surreptitious value judgments. However, we do accept, and underscore, what each assumes in castigating the other: that it is an empirical issue and that only those principles that guide scientific enquiry have a rightful place in its adjudication. We also accept that values nevertheless sometimes 
figure in such adjudications, and may well have in the Chaoulli Court. We hasten to add, however, that, whether in the Chaoulli Court or in public policy discussion more generally, when a policy issue is argued on empirical grounds, as if the answer to it turned on the evidence, it is a matter of conjecture whether values have been at work illicitly behind the scenes.

Values invariably are engaged and at stake in policy issue discussions, but how are they engaged and how should they be? We believe that explicitness is the appropriate norm and, related to that, clarity, openness, and transparency. Often, the values informing a policy position are simply unthematized - perhaps taken for granted and simply assumed, or held in a confused way. There is nothing wrong with that per se, but policy controversy will become clearer, more open, and more transparent if they are brought to explicitness. Additionally, however, unthematized values may be engaged and at work in policy discussions in a way that we believe is illicit and that makes it more difficult to bring them to explicitness. This is the case when an argument purported to turn on a given ground turns surreptitiously on a value that is not made explicit. In this event, the decisive value is not just unthematized but obfuscated, concealed, or otherwise obscured. Ostensible disagreement with respect to the purported ground is then a proxy for a disagreement that turns on some other undisclosed ground, a façade behind the scenes of which undisclosed values are doing the real work.

We offer three reasons for supposing this is happening to some extent in the public debate about private insurance - in particular, in the ostensibly empirical disagreement about its effects on the publicly funded system. These reasons are bias, expediency, and suppression of value negation.

\section{The Challenge of Bias}

To begin with bias, in any policy discussion it is essential to distinguish between facts and issues that turn on the evidence and issues that turn on values; typically, however, the two are intertwined. ${ }^{57}$ The values we hold act as filters of facts and influence our assessment of evidence without our explicitly recognizing it - we read the facts as we would wish them to be, rather than as they are.

Did this happen in the Chaoulli Court? We can only conjecture. Does it happen in policy discussion surrounding the policy issue? Again, we can only conjecture, but we would be surprised if it does not, at least in some instances. The tendency at work here is a fundamental fact of the human condition. When a policy issue decisively turns on an empirical side issue, there is good reason to suppose that the assessment (and even generation) of relevant empirical evidence is prone to bias. The line between evidence-based policy-making and policy-based evidence-making is clear and sharp in principle, but in practice it can be difficult to discern. The best we can do is to be vigilant, not just with others, but above all with ourselves. Vigilance is what the spirit of scientific enquiry enjoins as it builds checks on bias and conflict of interest into its methods; vigilance is also enjoined by the commitment to explicitness, clarity, openness, and transparency.

\footnotetext{
57 The distinction between facts and values is the subject of controversy beyond the scope of this paper. For the purpose of our analysis, we assume this distinction, as it is more or less implicit in back-and-forth recriminations about ideology in Chaoulli and in policy commentary surrounding the case.
} 


\section{The Challenge of Expediency}

It is often expedient to argue from a values ground other than the one that really matters to us if doing so is thought to be more likely to win support for the cause we favour, albeit favouring it on grounds other than those we argue from and that we do not make explicit.

If, as we suppose, absolute egalitarianism and libertarianism are known to be somewhat less palatable to Canadian public opinion than is welfare egalitarianism, that would be reason for those who hold one or other of these values positions and who favour or oppose the prohibition on this ground to argue their case as if accepting the more palatable welfare egalitarian values ground. ${ }^{58}$ Libertarians could hook their value to the empirical claim that private insurance would not diminish the quality of the publicly funded system; egalitarians could hook their value to the contrary claim. In doing so, either could cling dogmatically to such threads of empirical evidence as supported the outcome they sought without having to make explicit, much less to defend, the less palatable value that really informs their position on the policy question and, subordinate to that, on the evidence. ${ }^{59}$

Perhaps the lack of focus in public debate on private health insurance indicates that there are few absolute egalitarians and libertarians in the policy arena, and that welfare egalitarianism is a very big tent. But we believe it is likely that some who argue the empirical issue as if from the welfare egalitarian position are closet libertarians or absolute egalitarians who keep their values out of sight for reasons of expediency. Of course, this view is behind charges that the empirical debate in the Court was ideologically driven. And it is in recognition that this sometimes occurs in policy discussion, and in order to tease out values that may be hidden behind the empirical argument, that we pose our questions about that empirical question in hypothetical terms. We distinguish both absolute egalitarianism and libertarianism from welfare egalitarians according to how they would position themselves on the policy issue if the evidence about the effect of private insurance on the publicly funded system were at odds with the policy outcome they desire on value grounds other than those of the welfare egalitarian.

$\overline{58}$ Forget ("Promises, Promises") observes that Canadians prefer to "wear their ideology 'lite"” and avoid overt ideological terms. For example, most Canadians today (and, as Forget points out, even members of Canada's "socialist" party) prefer not to call themselves socialists because the term has picked up strong negative connotations. Forget reminds us that the evolution of medicare in Canada has "socialist underpinnings" going back to a time when "socialist" did not have such a pejorative status and Canadians were more receptive to socialist ideas. Today, explicit reference to the socialist underpinning of medicare is more likely to put Canadians off a prohibition against private insurance than to win them to it.

59 There is a interesting similarity here with what Freud called "kettle logic": "The defense put forward by the man who was charged by one of his neighbors with having given him back a borrowed kettle in a damaged condition. The defendant asserted, first, that he had given it back undamaged; secondly that the kettle had a hole in it when he borrowed it; and, thirdly, that he never borrowed a kettle from his neighbor at all. So much the better if only a single one of these three lines of defense were to be accepted as valid the man would have to be acquitted." See Sigmund Freud, "The Interpretation of Dreams," in Standard Edition of the Complete Psychological Works of Sigmund Freud, vol. 4, edited and translated by James Strachey (London: Hogarth, 1900 [1953]), pp. 119-120. 


\section{The Challenge of Value Conflict Avoidance}

As another reason the values in play and at stake in policy discussion about private insurance may be not just unthematized but in some sense hidden or obscured, consider the social interest in avoiding or suppressing even the negation of values. Policy issues, fundamentally and essentially, are about values in tension or competition, which may be more or less explicit. Different policy options favour different values or value configurations, and to select one option over another is to privilege the values configuration it is based on. This same point can be put more harshly: to favour the values configuration underlying policy option A is to negate the values configuration underlying policy option $\mathrm{B}$. This highlights that policy choices involve tradeoffs: the opportunity cost of selecting option A is negating option B - there will be policy winners and policy losers.

Tragic policy choices are ones in which any of the available options negates some value or other and any of the values to be negated is of significant importance in society, and perhaps only marginally less important than the value affirmed in the selection of the preferred option that prevails at the end of the day. In Tragic Choices, Guido Calabresi and Philip Bobbit demonstrate a general social tendency to mask the negation that necessarily attends such policy choices or, what comes to the same thing, to mask the value judgment, as if all of the values we would like to hold are reconciled. The problem with explicitness is that it sharpens irreconcilable value conflicts and the necessity of making value judgments that negate one or more values. ${ }^{60}$

Alan Fiske and Philip Tetlock discuss what they call "taboo trade-offs," by which they mean "any explicit mental comparison or social transaction that violates deeply-held normative intuitions about the integrity, even sanctity, of certain forms of relationships and of the moralpolitical values that derive from those relationships." Taboo tradeoffs are treated as "impermissible," and when put starkly people often "respond with varying degrees of indignation." ${ }^{61}$ The value tradeoffs we pose are not taboo in the strict sense that Fiske and Tetlock discuss, but are similar and apt to occasion similar responses, including evasion.

In short, there are social psychological reasons for lack of explicitness about values and value tradeoffs. For example, the negation entailed by a value tradeoff is painful, or heightens anxiety - an affront to the view we would like to have of ourselves collectively or to our symbolic identity. To preserve this collective self-image or symbolic identify and to ward off the painful sting of anxiety, we hide or bury the negation that would challenge it.

${ }^{60}$ Guido Calabresi and Philip Bobbit, Tragic Choices: The Conflicts Society Confronts in the Allocation of Tragically Scarce Resources (New York: Norton, 1978).

61 Alan P. Fiske and Philip E. Tetlock, "Taboo Trade-offs: Reactions to Transactions that Transgress the Spheres of Justice," Political Psychology 18 (2, 1997): 256-257. Speaking more loosely than Fiske and Tetlock, we would add that frank discussion of the Canada Health Act has become somewhat taboo in Canadian society. Deschamps J. (Chaoulli, para. 16) notes that the "broad principles" of the Act "have become the hallmarks of Canadian identity" and that "the Canada Health Act has achieved an iconic status that makes it untouchable by politicians." Marmor, Okma, and Latham also speak of medicare as an icon in Canadian society. They add: "For this reason, there is understandable political reluctance to challenge directly the program's premises. On the other hand, the iconic status of Medicare makes it perfectly clear why the media - and Medicare's advocates - are on the hunt for threats to this widely 'valued' program" ("National Values, Institutions and Health Policies," p. 7). The Majority in Chaoulli certainly was not dazzled by this icon as they soberly interpreted the Canada Health Act and related documents and applied the relevant legal principles in working through the legal issues. The storm of indignation following the decision may be in part attributable to the Majority's breaking the taboo. 
Some such psycho-social dynamic may occur in Canadian society in connection with rationing and the "taboo" against explicitness about it. ${ }^{62}$ We like to think of ourselves as a compassionate society with a health care system rich enough to provide the best medically necessary care to anyone in need in a timely manner. If this is not possible, however, or possible only if we channel resources to the health care system at the expense of seriously underfunding the education system or other important social priorities, the opportunity cost of meeting all health needs with public payment may be too high to be acceptable. In this case, we have no option but to ration, recognizing that, in doing so, some may not get the best care available or not get it in a timely manner. ${ }^{63}$

Yet the very idea of rationing, and the negation ingredient in it, sounds harsh to our ears and is an affront to our collective image. And so we ration, sometimes pretending that we do not, sometimes claiming that rationing will do no harm by exploiting the elasticity of the concept of "medically necessary," and sometimes invoking values to conclude that some services and health care interventions are too costly for the benefits they generate. So, we suppress the value judgment and the negation of value it entails. Instead, we say that the intervention is not "medically necessary" or not "clinically indicated" or not "effective." ${ }^{64}$ The value judgment, and its painful negation, is thus buried or concealed; the issue, if explicitly discussed, is debated in terms of whether the intervention is indeed medically necessary, or in arcane regulatory rules for drug formularies, as if it were not about values at all.

${ }^{62}$ In the literature, rationing is sometimes referred to as the " $\mathrm{R}$ " word, in recognition of a taboo about speaking explicitly about it and acknowledging its reality. On this point, see Michael Yeo, "Ethics and Economics in Health Care Resource Allocation: Cost Effectiveness of the Canadian Health Care system," Working paper (Kingston and Ottawa: Queen's-University of Ottawa Economic Projects, 1993); Gregg M. Bloche and Elizabeth Jungman, "The 'R' Word," Journal of Contemporary Health Law and Policy 18 (2001): 633-639; and Robert Pear, "The 'R' word; Justice Souter takes on a health care taboo," New York Times, 22 February 2009. Wright ("Different Interpretations of 'Evidence,", p. 231) points out that rationing in the public system, which is unavoidable, necessarily promotes growth in private payment or private insurance as services or treatments "deemed uninsured in the public system" are picked up privately. This dynamic is one reason for a tendency on the part of politicians and commentators worried about the growth of private payment and insurance to avoid explicitness about the fact of rationing. Wright points out that "there is such profound reluctance on the part of politicians to engage the issue" that "it has almost been accorded taboo status" (p. 229). Of course, this is not to say that this taboo is so strong that explicit discussion about rationing never occurs in Canadian society; only that there is an aversion to it.

63 O'Neill and O'Neill find that the health income gradient is steeper in Canada than in the United States. They interpret this as reflecting that the rationing in Canada's health care systems is more of a barrier to access for lowincome individuals than is the U.S. price-based system. See June M. O'Neill and Dave M. O'Neill, "Health Status, Health Care and Inequality: Canada vs. the U.S.," Forum for Health Economics \& Policy 10 (1, 2008).

64 Claims about "cost effectiveness" are more likely to implicate value judgments; if such value judgments are explicit at the macro level, where decisions about what will be funded are made, they tend not to be so at the point of service, where decisions are made about what services will be offered or provided to the presenting patient. For example, to provide intervention $\mathrm{X}$ (say, a drug or a diagnostic test) to a cancer patient under condition $\mathrm{Y}$ would cost the public payer a lot while perhaps marginally extending the patient's life, leading to the decision that intervention X should not be paid for through the public purse. That of course, is a value judgment and one with a painful sting for cancer patients whose health needs may be negated by it. 
And it may be that some such dynamic occurs in Canadian society in the public discussion about private insurance, as it comes to focus on the empirical nature of the effect of private insurance on the publicly funded system. Perhaps the values that really are at stake - welfare, equality, and liberty, however these may be nuanced - all matter enough to us that we want the issue to be resolved without any of them being negated. But they cannot be reconciled: liberty will be infringed or inequality in the extensive sense will increase; or, depending on the facts, the quality of the system will diminish or an opportunity to enhance it will be lost; or more than one of these things will happen. Whichever way, there is a negation, and the less explicit we are about the values in play and at stake, the less the sting of the negation. ${ }^{65}$ The empirical issue aside, talk about values may be welcome as long as they are discussed in terms that are vague and selective enough that the tradeoff with negated values is not made explicit.

65 Along these lines, the opinion of the Majority is very suggestive: with the removal of the prohibition, liberty will not be infringed. And, as it assessed the evidence, neither will the quality of the system be diminished. Moreover, as the Majority construed equality only in the restricted sense, neither will equality. To be sure, equality, in the extensive sense of the absolute egalitarian, will be decreased; however, for the Majority, equality in this sense did not figure in the picture, and its negation was not even registered. 


\section{CONCLUSION}

The debate about private insurance has been limited by a failure to articulate sharply the values engaged and in tension in the issue. In some ways, Chaoulli obscured the policy issue, rather than helped to clarify it. The distillation of the legal issue to a pivotal empirical issue reinforced a tendency in general policy discussion about private insurance to focus on this empirical issue to the neglect of values in tensions in the policy issue.

It may be, as critics have implied, that some or all of the members of the Majority were actually libertarians who adopted the welfare egalitarian position because the liberty argument had no foothold in the legal argument. Likewise, it may be that the Minority and various experts were absolute egalitarians similarly constrained to argue on welfare egalitarian grounds for reasons of expediency. In any event, the main and decisive argument in the Chaoulli Court turned on the empirical issue, as if it were essentially a debate between welfare egalitarians. At the end of the day, one might say, welfare egalitarianism prevailed; libertarianism got the outcome it sought (albeit on different grounds than the ones it cared about); and absolute egalitarianism lost the day, albeit on grounds other than the ones it cared about. Had the Majority found otherwise than it did on the empirical question and ruled the prohibition constitutional, welfare egalitarianism would still have prevailed, but absolute egalitarianism and libertarianism would have traded winning and losing places.

We do not claim that any of the Justices actually held the values positions we attribute to them or that libertarian and absolute egalitarian values positions were, in fact, at work illicitly in the disagreement about the empirical issue. The case can certainly be read that way, however, and we think it is at least a useful fiction. Regardless, we believe that the values and values-based positions we have constructed with reference to the Court are the main ones engaged by the policy issue. They are abstract types, representing different value configurations logically distinguishable with reference to positioning on the policy issue under different scenarios for answers to empirical questions. ${ }^{66}$ Under any of these positions, one could distinguish a variety of subpositions on how the values in tension are nuanced and on the reasons for the importance each is assigned relative to the others. However they may be nuanced, if the rather stark tradeoffs that divide the three abstract types we have distinguished are evaded, talk about values will only obscure the policy issue.

\footnotetext{
66 The three values-based positions we distinguished are approximate to those of Rawls (welfare egalitarian), Nielsen
} (absolute egalitarian), and Nozick (libertarian). However, this can be argued and nothing hangs on it for us. 
Moreover, we believe that some such subterranean drama of hidden values - as some suspect happened in the Supreme Court of Canada in the Chaoulli case - does happen in policy discussion about private insurance that is concentrated on the empirical issue. General policy discussion that is not constrained, in the way the discussion in the Court was, is less than explicit about values. We believe this is due at least in part to an unwillingness to face the values issues head on. We further believe that, to some considerable extent, values and value judgments are being surreptitiously introduced into a debate ostensibly about empirical issues. It serves one purpose or other that the values that are in play and at stake - welfare, equality, and liberty - are not clearly thematized, as if, at the end of the day, no one value configuration would prevail and no other would be negated. The policy debate thus occurs as if it were merely an empirical issue about the facts, and as if the values and value judgments engaged were scarcely made thematic at all. The values of the welfare egalitarian frame the discussion, without making the tensions and tradeoffs, or even its own values base, explicit. Libertarians and absolute egalitarians blend imperceptibly and without mark of distinction into the welfare egalitarian crowd, joining the empirical argument on the side of the outcome they desire on value grounds.

It is impossible be certain of such things as long as the argument takes place as if it turned on empirical evidence. But our test questions to distinguish absolute egalitarians and libertarians from welfare egalitarians do get at whether, or to what extent, the answer to the empirical question - positive effect, negative effect, or neutral - makes a difference as to one's position on the policy question. If the answer makes no difference, then some other value besides welfare - perhaps equality, in an extensive or even symbolic sense, or liberty certainly is in play and, we believe, should be explicitly acknowledged.

To a point, we agree with Claude Forget that we should address health policy issues — private insurance, in particular - with reference to the "the country's proclaimed fundamental values." ${ }^{\circ 7}$ The Chaoulli decision highlights some fundamental values agreement that Canadians have concerning medicare. There was no objection to the view that medicare's purpose is to meet the health care needs of Canadians, and consequently that the protection of the publicly funded system is sacrosanct.

We suppose that, as in the Chaoulli Court, in the court of public opinion there will be greater receptivity to welfare egalitarian values than to libertarian or absolute egalitarian ones if the values in tension are explicitly put. For the welfare egalitarian, private insurance is, at best, only contingently at odds with vigilant support for the publicly funded system. And depending on how one understands the fundamental values premises of the publicly funded system and the operative notion of equality, one can argue coherently that Canadian governments should provide necessary medical care for all Canadians and at the same time allow private insurance.

\footnotetext{
$\overline{67}$ Forget, "Promises, Promises," p. 393.
} 
We expect that, like welfare egalitarians, few Canadians would be prepared to negate it by prohibiting private insurance outside the system if doing so had a neutral effect on the quality of services available within the system. Liberty does matter for many Canadians, and judging from the increasing importance given to autonomy since the landmark decision (around the same time as the inception of universal health care in Canada) in Reibl v. Hughes has considerable importance within the publicly funded system. ${ }^{68}$ Whether liberty matters enough that Canadians would allow private insurance if it had a negative effect on welfare in the publicly funded system seems to us less clear. This being the test for distinguishing libertarians from welfare egalitarians, we think libertarians would have a harder time winning their case in the court of public opinion.

The publicly funded system has important symbolic meaning for many Canadians, associated with a sense not just of compassion but of something like solidarity and perhaps "social wellbeing." Canada is perceived to have embraced "socialized medicine" in the name of welfare and equality. Undoubtedly, equality matters a great deal in Canadian society, and the publicly funded system symbolizes this perhaps more strongly than any other Canadian institution. But however much it may have mattered at the inception of the universal health system, how much does it matter today? ${ }^{69}$

The premise that Canada should have a publicly funded system that meets the needs of all Canadians on equal terms and conditions was not at issue in the Chaoulli case. To be sure, there is room for disagreement about the level of quality the system should be able to sustain, given opportunity costs, but the basic values premise appears to be assumed and unquestioned in policy discussion. Also assumed and unquestioned, even by libertarians as we characterize them, is that, in distributing necessary care to Canadians, equality is sacrosanct. But equality within the system is different from equality between the system and outside it. We think that many Canadians care about equality in this latter sense as well; do they care enough that they would deny not just liberty but also welfare in its name? Here, it seems to us that, if they were to be explicit about their position vis-à-vis the willingness to trade off welfare for equality, the challenge absolute egalitarians face in the court of public opinion is even more daunting than that facing libertarians. ${ }^{70}$ It may be that the concern about equality can be nuanced in a way that avoids the appearance of an ignoble moral psychology. But however attractively one might be able to nuance equality or what it stands for, it will be difficult to make the case that it is important enough to sacrifice material welfare in its name.

$\overline{68}$ See Supreme Court of Canada, Reibl v Hughes (1980), 114 D.L.R. (3d) 1 (S.C.C.). The history of autonomy in the Canadian health context is complex, and it is somewhat arbitrary to trace its beginning to this case. To be sure, autonomy was engaged in this case in a very limited way, and has mutated considerably and expansively in the health system.

69 Forget ("Promises, Promises") may be right in supposing that Canadian values have changed since the inception of medicare, when socialist ideas enjoyed greater support.

70 Romanow says: "Some have described it as a perversion of Canadian values that they cannot use their money to purchase faster treatment from a private provider for their loved ones. I believe it is a far greater perversion of Canadian values to accept a system where money, rather than need, determines who gets access to care" (Building on Values, p. xx). Perhaps, but we think Courchene may be more in touch with the values Canadians really do hold today in asking how we will convince aging baby boomers that they can spend their higher pension incomes and savings on anything they want except their health care ("Medicare as a Moral Enterprise," p. 13). The post-Chaoulli polling data reviewed by Gaudreault-Desbiens, and Panaccio suggest a qualified receptivity to increased private sector involvement suggestive of the welfare egalitarian position, at least in Quebec ("Chaoulli and Quebec's

Charter of Human Rights and Freedoms," p. 46). 
In thus sketching what we take to be the present values landscape in Canadian public opinion concerning private insurance, we hasten to add an important qualification to our agreement with Forget about debating the issue with respect to the "country's proclaimed values."

Evidence about what those values are, in fact, is bound to be controversial and its interpretation may be influenced by the views of antagonists about what they would like to believe, and have others believe, those values are. However, supposing that we could indisputably discern these values empirically, that would not resolve the policy issue, which, as essentially a moral issue, is not about which values in fact prevail but about which ones ought to. If this point is not recognized, the policy issue is conflated with an empirical issue, in a manner not dissimilar to how we suppose it has occurred in connection with the empirical issue of the effect of private insurance on the publicly funded system. ${ }^{71}$

Regardless, we believe that more careful and explicit reference to the values we have clarified and explicated, and to the probing tests we have proposed to distinguish them, would make for clearer, more open, and more transparent public debate about private insurance. To be sure, it may be that few policy commentators, if pushed, would embrace publicly the absolute egalitarian or libertarian position, but this would mean that there really is not much of a policy debate at all. All of the passion invested in the policy question would appear to be that of welfare egalitarians engaged in a scientific dispute about an empirical issue, albeit perhaps suspecting that their opponents on the other side of the empirical issue are really libertarians or absolute egalitarians in welfare egalitarian clothing. ${ }^{72}$ We claim that the values of scientific enquiry are the values that have guided our analysis. At least, we would like to believe this is so, for it is an open question, of course - of the kind about which we ourselves enjoin vigilance - whether other values, undisclosed, have surreptitiously entered into our approach. ${ }^{73}$

71 The rhetorical move whereby values identified as core Canadian ones are used as trumps in policy debate is typical. Our point here is not that, in such moves, Canadian public opinion is not correctly ascertained, but rather that the policy issue cannot be resolved by appealing to public opinion. This is not to say that one should not be guarded about empirical claims concerning public opinion. No doubt it sometimes happens that Canadian public opinion is used like a ventriloquist's puppet to mouth words coming from the one pulling the strings. In the name of Canadian values, ascertained according to some methodology or other of dubious scientific validity, vaguely elaborated not much beyond platitudes, and conducted or commissioned by persons with known positions on the policy issue, a policy option is ruled out because it is found to be inconsistent with these values supposedly discovered.

We distinguished these three positions sharply in order to focus the underlying values at the points where they are in tension. We expect people with absolute egalitarian or libertarian leanings might recoil, not just publicly, but also privately, if pushed by the test questions we pose and retreat to the welfare egalitarian position. We allow that some might hold the primary libertarian and absolute egalitarian values more or less strongly, short of accepting the tradeoffs we push. Adjusting for this, we could reframe our terminology to express a difference of degree, rather than of kind, and under the umbrella of welfare egalitarianism distinguish absolute welfare egalitarians and libertarian welfare egalitarians according to how strongly they leaned to one or the other value, short of accepting the tradeoffs that would squarely place them in the libertarian or absolute egalitarian positions.

73 Some critics may believe that the idea that private insurance could have a salutary effect on the publicly funded system is so preposterous that for us to entertain this possibility, even for methodological purposes, is evidence of a bias in favour of liberty. Suffice it to say, that interpretation would be to misunderstand completely the analysis we undertake here and how it can be useful to consider counterfactual arguments in testing and articulating value positions. 
The authors would like to thank the reviewers for helpful comments on this paper in draft, Ron Kneebone and staff of the Institute for Advanced Policy Research and The School of Public Policy for guidance throughout, and Barry Norris for his careful copy editing. Michael Yeo would like to thank Norman Cheadle and Patrick Gamsby for their detailed comments, and to thank Carole Lucock not only for going over the draft in detail but also for so many hours (never enough time!) of rich conversation about the ideas the paper approaches.

\section{About the Authors}

Michael Yeo is an Associate Professor and Chair in the Department of Philosophy at Laurentian University. He has published extensively on health care ethics and policy.

Herb Emery received his BA (Honours) in economics from Queen's University in 1988 and PhD in economics from the University of British Columbia in 1993. He has taught at the University of Calgary since 1993 and is now the Svarre Professor of Health Economics, a joint appointment between the Department of Economics and the Department of Community Health Sciences in the Faculty of Medicine.

Daniel Kary has an MA (Philosophy) from Memorial University. 